\title{
Hydrogen cyanamide poisoning; rare but serious, case study
}

\author{
Reham Nafad Elbendary ${ }^{1}$,Nazih Ramadan ${ }^{1}$ \\ ${ }^{1}$ Department of Forensic Medicine and Clinical Toxicology, Faculty of Medicine, \\ Cairo University, Cairo, Egypt.
}

Corresponding author: Reham Nafad Elbendary

E-mail address: Dr.rehamnafad@hotmail.com

Date of submission: 15 December 2020

Revised at: 7 March 2021

Accepted at: 7 March 2021

\begin{abstract}
Background :Pesticides are used widely and are one of the major causes of intentional poisoning. Hydrogen cyanamide is highly toxic, causing massive vomiting, hypotension, shock, and drowsiness. Case report: Adult male patient in the third decade was admitted to Cairo university toxicology center in January 2015 with suicidal ingestion of an unknown amount of known hormonal plant regulator called DORMEX (active ingredient is hydrogen cyanamide). The patient experienced severe vomiting and diarrhea. He was tachypneic, with low blood pressure, and his pupils were bilaterally constricted. ABG shows metabolic acidosis with normal other routine labs. Sodium bicarbonate was given till ABG improved. Later, the patient was shocked, Dopamine and noradrenaline were started, and then he was stabilized. Then after 5 hours patient was arrested, C.P.R. was started, but the patient died .Conclusion: This case may be, in our national toxicology center, the first reporting poisoning case with ingestion of hydrogen cyanamide with suicidal intent. The case rapidly deteriorated despite good supportive treatment, ended by death due to shock and refractory metabolic acidosis.
\end{abstract}

Keywords: severe, poisoning, hydrogen cyanamide

\section{INTRODUCTION}

Pesticides are used widely and are one of the major causes of occupational, accidental, and intentional poisoning; self-poisoning may be the major cause [1]. Hydrogen cyanamide (which is known in the market by Dormex) is categorized as a plant growth regulator which is used by farmers in grapevine bud-breaking. It may cause if used without precaution, severe cutaneous reactions, which may be as severe as Stevens-Johnson syndrome [2]. Cutaneous and external exposures of hydrogen cyanamide are more common; however, some reported cases were very dangerous and may be ended by the termination of life, so awareness about this poison and its dangers is necessary and important to provide early and aggressive management because there is no, till now, specific antidote available for it [3]. For the national institute of environmental and clinical toxicology and research (NECTR), Cairo University, Egypt, such a case of hydrogen cyanamide intentional ingestion hasn't been seen before.

\section{CASE REPORT}

An adult male patient in the third decade presented to the national 
institute of environmental and clinical toxicology and research (NECTR), Cairo University, Egypt, on 31 January 2015 at $6: 30 \mathrm{pm}$ with suicidal ingestion of an unknown amount of known hormonal plant regulator called DORMEX (active ingredient is hydrogen cyanamide) since 3 hours. His family said that the patient vomited reportedly just after ingestion, and this was accompanied by diarrhea. On physical examination, the patient was confused, responding to painful stimuli and Glasgow Coma Scale was 8, pulse $110 \mathrm{bpm}$ regular, blood pressure was $100 / 60$, his respiratory rate was $30 / \mathrm{min}$, pupils were constricted on both sides and look like pinpoint which was similar to picture of organophosphate poisoning. Pulse oximeter showed oxygen saturation of $86 \%$, which improved to $97 \%$ after the patient was connected to a T-tube. Central venous pressure (CVP) was about $8 \mathrm{~cm} \mathrm{H}_{2} \mathrm{O}$. On examination of the chest, there was coarse crepitation on both sides. Other physical examinations did not show significant findings. Pseudo-choline esterase was measured as organophosphorus poisoning was suspicious from clinical examination, but it was normal. Routine labs were done, but all were within normal ranges except metabolic acidosis (Table 1).

Because of low G.C.S. and decreased $\mathrm{O} 2$ saturation, an endotracheal tube was inserted and connected to T-tube on a (10L) oxygen source. The patient was given Atropine (suspecting organophosphate cotoxicity), and intravenous fluids were added to treat hypovolemia. Decontamination was done rapidly by Gastric lavage, and activated charcoal was given with the aid of a ryel tube. For metabolic acidosis, I.V. Sodium bicarbonate was given at dose 1-2 $\mathrm{mEq} / \mathrm{kg}$, then $\mathrm{ABG}$ was repeated, which revealed minor improvement. Therefore, bicarbonate was added continuously at a rate $(25 \mathrm{mEq} / \mathrm{h})$ and adjusted by repeated $A B G$ analysis.

At approximately $4 \mathrm{am}$, again, the patient was severely shocked; Central venous pressure decreased to about 3 $\mathrm{cm}$ of $\mathrm{H}_{2} \mathrm{O}$. Noradrenaline was started at a rate of $5 \mu \mathrm{g} / \mathrm{kg} / \mathrm{min}$ and combined with Dopamine at a rate of $5 \mu \mathrm{g} / \mathrm{kg} / \mathrm{min}$, in addition to saline, so the patient was finally stabilized.

However, suddenly in the early morning at 8:30 am, the patient was arrested, so C.P.R. started; adrenaline (1 mg IV) was given and repeated twice, followed by IV sodium bicarbonate. Despite all these supportive measures, unfortunately, the patient didn't survive.

\section{CASE DISCUSSION}

The clinical picture of this case (recurrent vomiting and diarrhea, constricted pupils, chest crackles, hypotension) was similar to organophosphate poisoning giving suspicion of co-ingestion of organophosphate compound, so Atropine was given on admission until it was excluded by pseudo-choline esterase enzyme level.

Centers for Disease Control and Prevention (C.D.C.) [4] reported 23 cases of acute illness ( Italy in 2001); 22 of them resulted from occupational exposure to Hydrogen cyanamide while mixing, preparing, or applying it, and one was from unintentional ingestion. This case( ingestion) became seriously shocked, with coma, constricted pupils, and hepatic injury, and was admitted to I.C.U.

Similar to the current case, [3] reported a case of; 22-year-old male with a history of consuming approximately $150 \mathrm{ml}$ of hydrogen cyanamide; he was seriously ill and showed symptoms of severe shock and metabolic acidosis. Their case has rapidly deteriorated, and they died after 12 hours of supported management. 
Table 1: laboratory parameters of the patient on admission

\begin{tabular}{|l|l|}
\hline Lab parameter & Patient results \\
\hline Random blood glucose & $183 \mathrm{mg} / \mathrm{dl}$ \\
\hline A.L.T. & $28 \mathrm{U} / \mathrm{L}$ \\
\hline A.S.T. & $22 \mathrm{U} / \mathrm{L}$ \\
\hline H.B. & $14 \mathrm{~g} \%$ \\
\hline creatinine & $1.2 \mathrm{mg} / \mathrm{dl}$ \\
\hline Urea & $42 \mathrm{mg} / \mathrm{dl}$ \\
\hline T.L.C. & 13000 \\
\hline PLT. & 268000 \\
\hline P.T. & 13.8 \\
\hline I.N.R. & 1.24 \\
\hline P.H. & $\mathbf{7 . 2 4}$ \\
\hline HCO3- & $\mathbf{1 4}$ \\
\hline P.CO2 & $\mathbf{3 8}$ \\
\hline Serum Potassium & $4.1 \mathrm{mmol} / \mathrm{l}$ \\
\hline sodium & $136 \mathrm{mmol} / \mathrm{l}$ \\
\hline Pseudocholine esterase enzyme & Normal \\
\hline
\end{tabular}

\section{CONCLUSION}

This case may be, in our national toxicology center, the first reporting poisoning case with ingestion of hydrogen cyanamide in a suicidal manner. The case rapidly deteriorated despite good supportive treatment, ended by death due to shock and refractory metabolic acidosis.

Further studies must be done to identify causes of rapid deterioration and better life-saving measures as there is no antidote for hydrogen cyanamide.

Also, awareness of its systemic complications and early aggressive treatment is recommended to reduce mortality.

Governmental efforts should encourage to manufacture alternatives with fewer side effects to protect from exposure.

\section{REFERENCES:}

D. Gunnell, M. Eddleston, M.R. Phillips, F. Konradsen, The global distribution of fatal pesticide self-poisoning: systematic review., B.M.C. Public Health. 7 (2007) 357.

doi:10.1186/1471-2458-7-357.

A.C. Inamdar, A. Palit, Cutaneous reactions simulating erythema multiforme and Stevens-Johnson syndrome due to occupational exposure to a plant-growth regulator., Indian J. Dermatol. Venereol. Leprol. 73 (2007) 3302. 
http://www.ncbi.nlm.nih.gov/pub med/17921614.

P. Kempegowda, S. Sheshadri, S. Kumar, U. Sudhir, DORMEX ; hydrogen cyanamide poisoning, J. Emerg. Trauma. Shock. 4 (2011) $435 . \quad$ doi:10.4103/09742700.83894 .

Centers for Disease Control and
Prevention (C.D.C.), Pesticiderelated illnesses associated with the use of a plant growth regulator--Italy, 2001., MMWR. Morb. Mortal. Wkly. Rep. 50 (2001) 845-7. http://www.ncbi.nlm.nih.gov/pub med/11665844. 


\title{
الملخص العربي
}

\section{تسمم سياناميد الهيدروجين دراسة حالة نادرة ولكنها خطيرة}

\author{
ريهام نفاد البندارى,نزيه رمضان \\ قسم الطب الثر عى والسموم الاكلينيكية, كلية الطب ,جامعة القاهرة
}

تستخدم مبيدات الآفات على نطاق و اسع و هي أحد الأسباب الرئيسية للتسمم المتعدد. ويعد مركب سياناميد الهيدروجين شديد السمية ؛حيث يتسبب في القيء الثديد و انخفاض شديد في ضغط الدم و الصدمة القلبية.

تقرير حالة: تم قبول مريض بالغ من الذكور في العقد الثالث في مركز السموم بجامعة القاهرة في يناير 2015 مع ابتلاع انتحاري لكمية غير معروفة من منظم نبات هرموني معروف يسمى DORMEX شديدين ، مع انخفاض في ضغط الدم وتقلص كلتا مقلتي العين. تم عمل التحاليل الروتينية فظهر في تحليل غاز ات الدم اضطر اب في بيكربونات الصوديوم و حموضة بالدم اما باقي التحاليل الروتينية كانت كلها سليمه. تم إعطاء بيكربونات الصوديوم حتى تتحسن الغاز ات بالدم ولكن في وقت لاحق ، أصيب المريض بالصدمة القلبية ، وبدأ اعطاؤه الدوبامين و النور ادرينالين ، ثم استقرت حالته. ثم بعد 5 ساعات توقف قلب المريض و بدأ الإنعاش القلبي الرئوي ، ولكن توفي المريض.

الخلاصة: قد تكون هذه الحالة ، في مركزنا القومي للسموم ، أول حالة إبلاغ عن حالة تسمم بابتلاع سياناميد الهيدروجين بنية انتحارية. تدهورت الحالة بسر عة على الرغم من العلاج الداعم الجيد ، و انتهت بالموت بسبب الصدمة القلبية. 